University of Nebraska - Lincoln

DigitalCommons@University of Nebraska - Lincoln

USGS Staff -- Published Research

US Geological Survey

2004

\title{
An association of benthic foraminifera and gypsum in Holocene sediments of estuarine Chesapeake Bay, USA
}

John Cann

University of South Australia, john.cann@unisa.edu.au

Thomas Cronin

US Geological Survey

Follow this and additional works at: http://digitalcommons.unl.edu/usgsstaffpub

Part of the Geology Commons, Oceanography and Atmospheric Sciences and Meteorology Commons, Other Earth Sciences Commons, and the Other Environmental Sciences Commons

Cann, John and Cronin, Thomas, "An association of benthic foraminifera and gypsum in Holocene sediments of estuarine Chesapeake Bay, USA" (2004). USGS Staff -- Published Research. 908.

http:// digitalcommons.unl.edu/usgsstaffpub/908

This Article is brought to you for free and open access by the US Geological Survey at DigitalCommons@University of Nebraska - Lincoln. It has been accepted for inclusion in USGS Staff -- Published Research by an authorized administrator of DigitalCommons@University of Nebraska - Lincoln. 


\title{
An association of benthic foraminifera and gypsum in Holocene sediments of estuarine Chesapeake Bay, USA
}

\author{
John Cann ${ }^{1 *}$ and Thomas Cronin ${ }^{2}$ \\ $\left({ }^{1}\right.$ School of Geoscience, Minerals and Civil Engineering, University of South \\ Australia, Mawson Lakes Boulevard, Mawson Lakes, South Australia, 5095, \\ Australia; ${ }^{2}$ US Geological Survey, Reston, VA 20192, USA)
}

Received 18 June 2001; revised manuscript accepted 8 May 2003

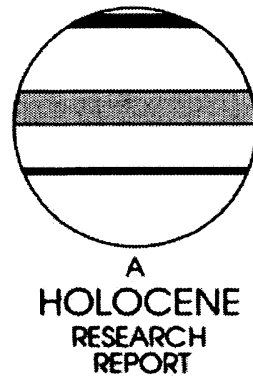

\begin{abstract}
Two cores of Holocene sediments recovered from the Cape Charles Channel of Chesapeake Bay yielded radiocarbon ages of about 6.8 to $5.8 \mathrm{ka}$ for the lower intervals. Fossil foraminifera preserved in these lower sediments are dominated by species of Elphidium, which make up about $90 \%$ of the assemblage throughout, and probably signify deposition in hypersaline waters. Buccella frigida and Ammonia beccarii are the only other species commonly present. Hypersalinity of bottom waters seems to have been maintained by water-density stratification in a basin-like section of the channel. In core PTXT-4-P-1 transition to modern Chesapeake conditions, in which numbers of Ammonia beccarii exceed those of Elphidium, commenced about 400 years ago. In core PTXT-3-P-2 hypersalinity is further signified by the presence of abundant euhedral crystals of gypsum in association with the fossil Elphidium. This occurrence of gypsum is not attributed to palaeoclimatic aridity, but rather to inflow of groundwater from adjacent gypsiferous Miocene strata. The study shows that in palaeoclimatic investigations the significance of the presence of gypsum should be evaluated with caution - it does not necessarily signify an evaporative regime.
\end{abstract}

Key words: Chesapeake Bay, estuary, foraminifera, gypsum, Holocene, hypersalinity, palaeoclimate.

\section{Introduction}

Chesapeake Bay, also referred to as 'the Chesapeake', is situated on the eastern coast and is the largest estuary of the United States. From the north, where the Susquehanna River debouches into the estuary, it is more than $300 \mathrm{~km}$ to the bay mouth in the south, where the estuary interfaces with the Atlantic Ocean. Average width is about $20 \mathrm{~km}$ but the boundaries are irregular, with 19 major estuarine tributaries and several hundred lesser tidal creeks, that together have created more than $7000 \mathrm{~km}$ of tidal shoreline. The cores that are the subject of this paper were taken from Holocene sediments adjacent to the mouth of the tributary Patuxent River (Figure 1). The Chesapeake hosts a richly diverse fauna of marine invertebrates, fish and birds (Lippson and Lippson, 1997) and is thus of great economic and recreational significance.

The modern Chesapeake is the expression of the postglacial marine transgression into the coastal tract of the Susquehanna fluvial system. At the height of the last glacial, oxygen isotope stage 2 , about $18 \mathrm{ka}$, when sea level was $c$. $130 \mathrm{~m}$ lower than it is now (e.g., Chappell and Shackleton, 1986; Chappell et al., 1996), the Susquehanna River flowed down its emergent valley and across more than $100 \mathrm{~km}$ of the exposed continental shelf before reaching the Atlantic Ocean. Subsequently, as global warming caused extensive melting of the continental ice sheets, sea level rose, submerging the continental shelf to the present coastline and flooding the coastal drainage system of the Susquehanna River. The culmination of this postglacial marine transgression about $7 \mathrm{ka}$ gave rise to the Chesapeake Bay of today (United States Geological Survey, 1998).

A series of seismic investigations within the estuary has revealed much detailed information about the bathymetry and Quaternary sedimentation (Colman and Hobbs, 1987; 1988; Colman and Halka, 1989a; 1989b). An entrenched palaeochannel of the Susquehanna River is thought to have formed during the times of lower sea level that followed the last interglacial, oxygen isotope substage $5 \mathrm{e}$, and particularly during the last (Wisconsinan) glaciation. Known as the Cape Charles Channel, it can be traced for the length of the estuary. Adjacent to the mouth of the Patuxent River, the Cape Charles palaeochannel is expressed as a deep, mid-bay channel which has an irregular profile. In the study area, water depth in the channel varies from 50 to $30 \mathrm{~m}$, generally shallowing

$10.1191 / 0959683604 \mathrm{hl} 738 \mathrm{rr}$ 


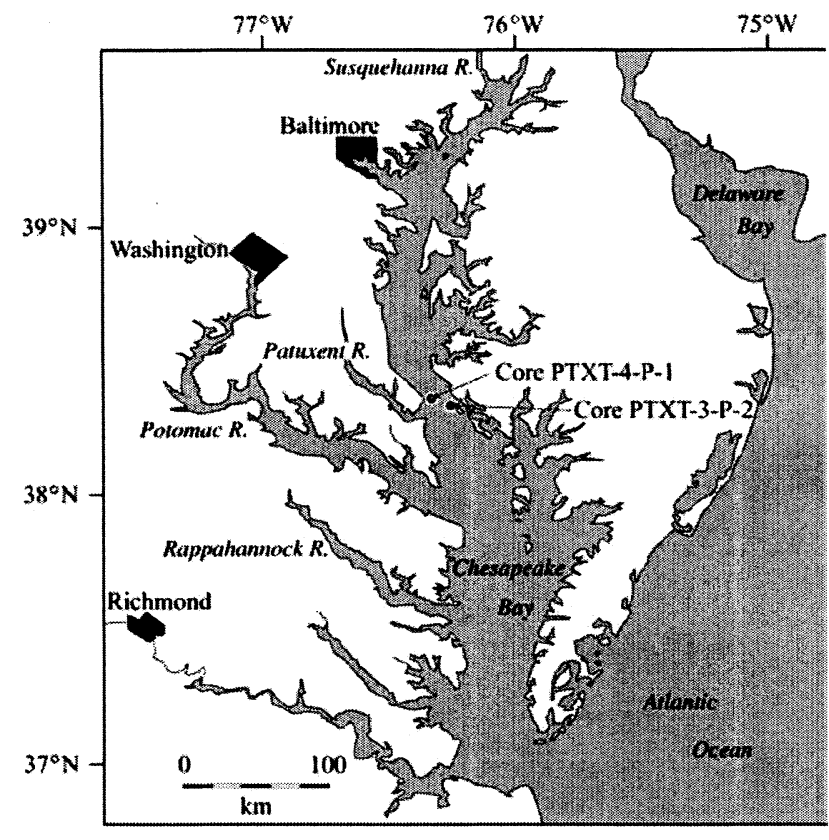

Figure 1 Map showing the outline of Chesapeake Bay and tributaries, and locations of the cores that are the subject of this paper. Core PTXT-4-P-1 (latitude N38 $21.48^{\prime}$, longitude $\mathrm{W} 76^{\circ} 20.25^{\prime}$ ) was taken in water $18 \mathrm{~m}$ deep. Core PTXT-3-P-2 (latitude N38 $20.00^{\prime}$, longitude $\mathrm{W} 76^{\circ} 18.58^{\prime}$ ) was taken in water $22.5 \mathrm{~m}$ deep.

southward. Two additional palaeochannels that represent earlier Pleistocene lowstands of sea level, such as oxygen isotope stages 6 and 8, have also been recognized.

Underlying the postglacial (mostly Holocene) and older Pleistocene sediments are Tertiary strata into which irregular Quaternary unconformities have been cut (Figure 2). Landbased geological mapping suggests that these strata are fossiliferous marine sediments of Miocene age. For example, the St Marys Formation of Middle to Late Miocene age crops out above sea level on the western shore of the Chesapeake north of the Patuxent River, and along the southern bank of the Patuxent River (Shattuck, 1904; 1907). It is likely that in the study area the deep Cape Charles palaeochannel has been cut into the St Marys Formation (Colman and Halka, 1989b).

The seismic studies referred to above suggest that most of the pre-Holocene deposits were eroded during lowstands of sea level and that only remnants of the Pleistocene sediments have been preserved in the deepest parts of the palaeochannels. Postglacial sedimentation has been most pronounced in the palaeochannels. The lowermost sediments are fluvial gravels and coarse sands that were deposited during the erosive episode of the stage 2 sea-level lowstand. As sea level rose following the Wisconsinan glaciation, relatively finer-grained sediments were deposited in the fluvial channels in response to rising base level. Subsequently, marine incursion into the valleys saw a transition to estuarine conditions and deposition of mud, muddy sand and peat. The results of the most recent seismic studies are in accord with this scenario (Vogt et al., 2000a; 2000b; Halka et al., 2000).

At the bay mouth, sand derived from the mid-Atlantic inner continental shelf accumulated in response to the postglacial sea-level rise. Today, sediments are delivered to the bay mouth mostly by southerly longshore drift along the eastern coast, and thence into the bay by bayward net tidal transport. Thus, throughout the Holocene, an extensive prograding sand wedge has developed (Colman and Hobbs, 1987). This depositional feature, which forms a partial barrier at the bay mouth, has the potential to restrict circulation within the Chesapeake and to promote density stratification of waters within the channels. Also, locally thick deposits of sediment in the vicinity of the mouth of the Rappahannock River have completely filled the Cape Charles Channel. Thus there exist channel environments $c .40 \mathrm{~m}$ deep north of this area which similarly might lead to density stratification. Finally, sedimentation at the mouths of the major tributaries, such as the Patuxent River, has resulted in the formation of sill deposits which partly restrict interchange of waters.

Foraminifera are common throughout the modern sediments of the Chesapeake, its estuarine tributaries and the
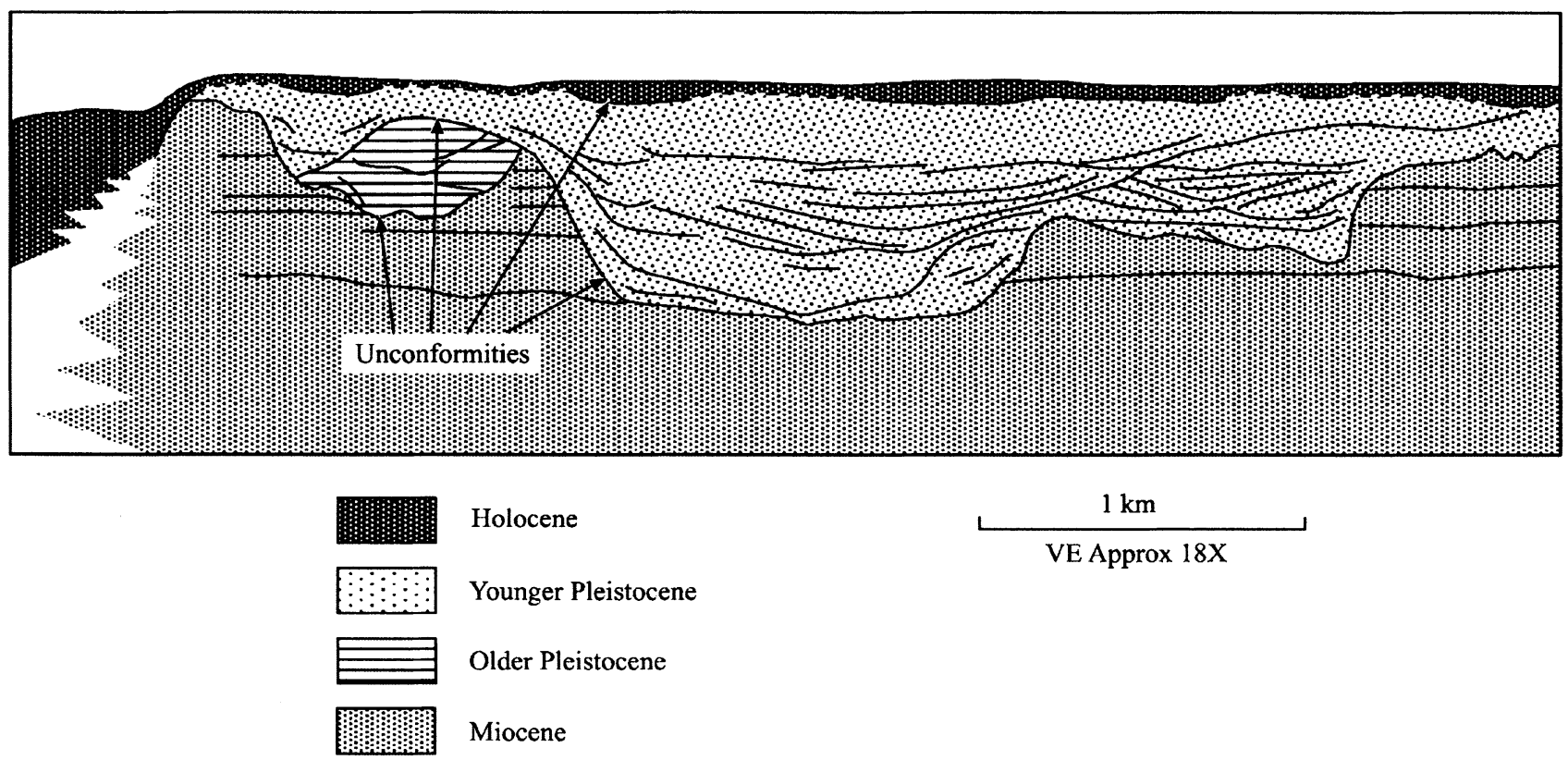

Holocene

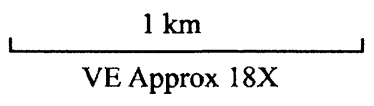

Younger Pleistocene

Older Pleistocene

Miocene

Figure 2 A typical Chesapeake submarine stratigraphic section, inferred from seismic data. The Cape Charles palaeochannel lies to the west. In the study area, the Miocene sediments are thought to include the St Marys Formation. After Colman and Hobbs (1988). 
adjacent saline wetland marshes, and the distribution of their species has been the subject of several previous investigations (Buzas, 1974; Ellison et al., 1965; Ellison and Nichols, 1970; 1976; Ellison, 1972; Nichols and Norton, 1969). The findings of these investigations and observations of the present authors lead to some general conclusions concerning the distributions of some selected species.

Buccella frigida is a species which is common in the coastal and shelf waters north of Chesapeake Bay (Culver and Buzas, $1980 ; 1981)$. Close to the bay mouth, foraminifera such as $B$. frigida are transported from the inner shelf into the estuary. Thus, the extent to which this species occurs in estuarine deposits is prima facie evidence of the marine influence in sedimentation. For most of the Holocene, B. frigida was an important component of the Chesapeake Bay foraminifera. From sediments recovered from the deep part of the Chesapeake Bay channel, core MD99-2209 due west of Washington, Cronin and Ishman (2000) found that, for the time interval $7000-2000$ yr BP, B. frigida comprised up to almost $15 \%$ of the foraminiferal assemblage. In overlying younger sediments, numbers declined to $2-3 \%$ and the last appearances of the species in that core is dated at about 500 years ago. The consistent recorded occurrence of $B$. frigida during the early to middle Holocene probably signifies more saline and better-oxygenated waters than those of the modern bay.

Within the main estuary and its tributaries, Ammonia beccarii is common. (Other workers, such as Karlsen et al., 2000, have referred the Chesapeake form of Ammonia to A. parkinsoniana). This species is well known for its tolerance to fluctuating and particularly low salinity, but there are established limits to environments in which it is viable. Growth and reproduction are possible only within a salinity range of $15-40 \%$ and temperatures of $42-45^{\circ} \mathrm{C}$ are lethal (Bradshaw, 1957; 1961).

Species of Elphidium that have been identified as $E$. clavatum and $E$. incertum favour the more saline lower reaches of the estuary, but are absent at salinities $<10 \%$ (Ellison and Nichols, 1970; 1976). Low-salinity sediments of tributaries and wetlands are characterized by an assemblage of agglutinated fauna in which species of Ammobaculites and related genera are dominant; other species commonly present include Ammoastuta salsa, Miliammina fusca and Trochammina inflata.

Scanning electron photomicrographs illustrating the common Chesapeake foraminifera are available in Ishman et al. (1999). Cronin et al. (2000) have applied the established environmental associations of these species to interpret distributions of fossil foraminifera (and other biota) within cored sediments of late-Holocene age. Thus they were able to infer a record of palaeosalinity, which in turn was taken as a proxy for rainfall and the extent of surface runoff into Chesapeake Bay.

Chesapeake Bay has long been acknowledged as a valuable natural resource which has been environmentally threatened by the activities of the $c .20$ million people who now live within the immediate vicinity of this water body. Furthermore, anticipated changes in climate and sea level are issues which may impact significantly on coastal processes. In order that effective management strategies can be progressively implemented, the United States Geological Survey and other agencies have recognized the need to determine the long-term natural history of the Chesapeake. Thus a programme was established in which cores of postglacial sediment taken from the estuary were examined for the many physical, chemical and biological indicators of the Holocene palaeoenvironments (Cronin et al., 1999).

\section{Materials and methods}

The work reported here details the foraminiferal records obtained for two exploratory piston cores taken from the western side of the modern Chesapeake Bay channel near the mouth of the Patuxent River (Figure 1). Core PTXT-4-P-1 (latitude $\mathrm{N} 38^{\circ} 21.48^{\prime}$, longitude $\mathrm{W} 76^{\circ} 20.25^{\prime}$ ) was taken in water $18 \mathrm{~m}$ deep. Core PTXT-3-P-2 (latitude N38 $20.00^{\prime}$, longitude W76 $18.58^{\prime}$ ) was taken in water $22.5 \mathrm{~m}$ in depth. Both cores recovered $>4 \mathrm{~m}$ of early- to middle-Holocene estuarine sediments, deposited within the Cape Charles palaeochannel during the final phases of the postglacial marine transgression.

Core PTXT-3-P-2 was taken in 1996 as part of an investigation of anthropogenic and climatic impacts on Chesapeake Bay for the past few centuries (Kerhin et al., 1998; Cronin et al., 1999). Although the younger sediments of this core contributed little within the timeframe of that study, it nevertheless recovered an early-Holocene succession which preserved significant assemblages of benthic foraminifera, and these constitute part of the materials for the present study. At the Maryland Geological Survey, X-radiographs of core PTXT3-P-2 revealed the presence of molluscan shells and fragments in the interval $290-434 \mathrm{~cm}$. The sediments consisted of $0-25 \%$ sand, $50-60 \%$ silt and $30-40 \%$ clay.

Seismoacoustic profiles at the site of core PTXT-4-P-1 revealed a succession of $c .13 \mathrm{~m}$ of Holocene sediments. The core recovered the uppermost $4.4 \mathrm{~m}$ of these deposits, in which sediments below $400 \mathrm{~cm}$ preserved significant numbers of middle-Holocene benthic foraminifera, complementing the faunal assemblages of the other core. Near the top of PTXT4-P-1, c. $50 \mathrm{~cm}$, there was a much younger horizon in which there were also significant numbers of foraminifera.

Both cores were sampled at $2 \mathrm{~cm}$ intervals for microfossil analysis. Samples were wet sieved over a $63 \mu$ mesh and the washed and dried residues were set aside for microscopic examination. Each of the washed and dried residual samples was sieved to provide two grain-size fractions for microscopic examination, $>250 \mu$ and $125-250 \mu$. Using conventional micropalaeontological techniques, all observed foraminiferal tests were extracted from the larger size fraction and transferred to a standard microfossil slide. The number of tests in this fraction of a sample provided an indication of the overall abundance of foraminifera in the sample. From the smaller size fraction, small amounts of sediment were randomly taken and sprinkled into a tray, and all observed tests were transferred to the microfossil slide. This procedure was repeated either until $>200$ tests had been isolated or until all tests had been picked from the subsample. The microscopically extracted tests were identified and counted. Subsequently, the relative abundances of species were determined as percentages of the subsample assemblages and expressed diagrammatically.

Fossil molluscs (Mulinia lateralis) and supplementary foraminifera from the cores were subjected to radiocarbon analysis through the US Geological Survey Graphite Laboratory and Lawrence Livermore Accelerator Mass Spectrometer, Livermore, California.

\section{Results}

Foraminifera were significantly present for most core samples in the bottom metre of PTXT-3-P-2 (Figure 4). Elphidium dominated the assemblages; it was the only genus represented in the $>0.250 \mu$ size fraction and on average it constituted $c$. $90 \%$ of the finer fraction. Buccella frigida and Ammonia beccarii were present in most samples, but rarely did they constitute more than a few percent. The most abundant occurrence of $B$. frigida, a species signifying marine influence, was $12 \%$ for the sample at core depth $416-418 \mathrm{~cm}$. Effectively, there were no other species present and significantly there were none of 


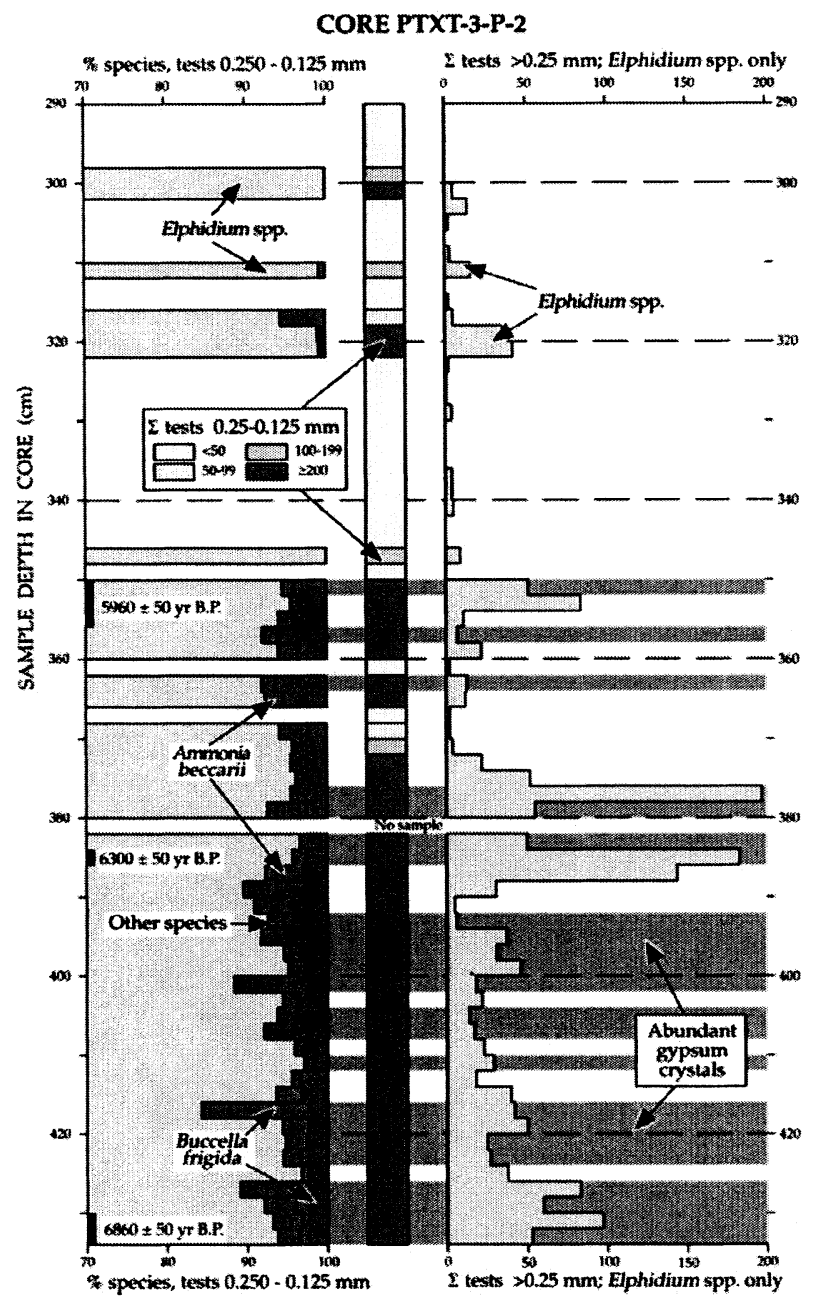

Figure 3 Distribution of foraminifera within the sampled intervals of core PTXT-3-P-2 together with uncorrected radiocarbon ages. The right column shows absolute numbers of tests $>0.250 \mu$ in each sample. These numbers are proportional to the density of tests in the sample and only Elphidium spp. was represented. The left column shows the relative abundance of Elphidium spp., Ammonia beccarii and Buccella frigida in the grain-size fraction $250-125 \mu$. Note that the percentage scale commences at $70 \%$. Elphidium spp. generally constitutes $\geq 90 \%$ of assemblages, signifying ongoing hypersalinity. $B$. frigida originates from the northeastern continental shelf. The low numbers of this species signify little direct inflow of Atlantic water. Low numbers of $A$. beccarii can be attributed to extreme hypersalinity. The middle column indicates the numbers of tests counted for the samples. Percentages are not given where $<50$ individuals were present. The grey shading indicates the presence of abundant euhedral crystals of gypsum.

the agglutinated fauna that are associated with waters of low salinity. Between 350 and $300 \mathrm{~cm}$ the core samples contained fewer tests, and above $300 \mathrm{~cm}$ foraminifera were rare or absent. Paucity of tests can perhaps be attributed to increased rates of sedimentation rather than an absence of foraminifera.

Crystals of gypsum were conspicuously present in many of the lower core samples (Figure 3). They were present in both the sediment grain-size subsamples and ranged in size to about $1 \mathrm{~mm}$ in length. These crystals were mostly euhedral with sharp edges and terminations, transparent and free of included matter.

In core PTXT-4-P-1, samples below $400 \mathrm{~cm}$ were similar to those of PTXT-3-P-2 in that Elphidium was dominant, and $A$. beccarii and $B$. frigida were minor components of the fauna (Figure 4). However, there was no evidence of gypsum. The

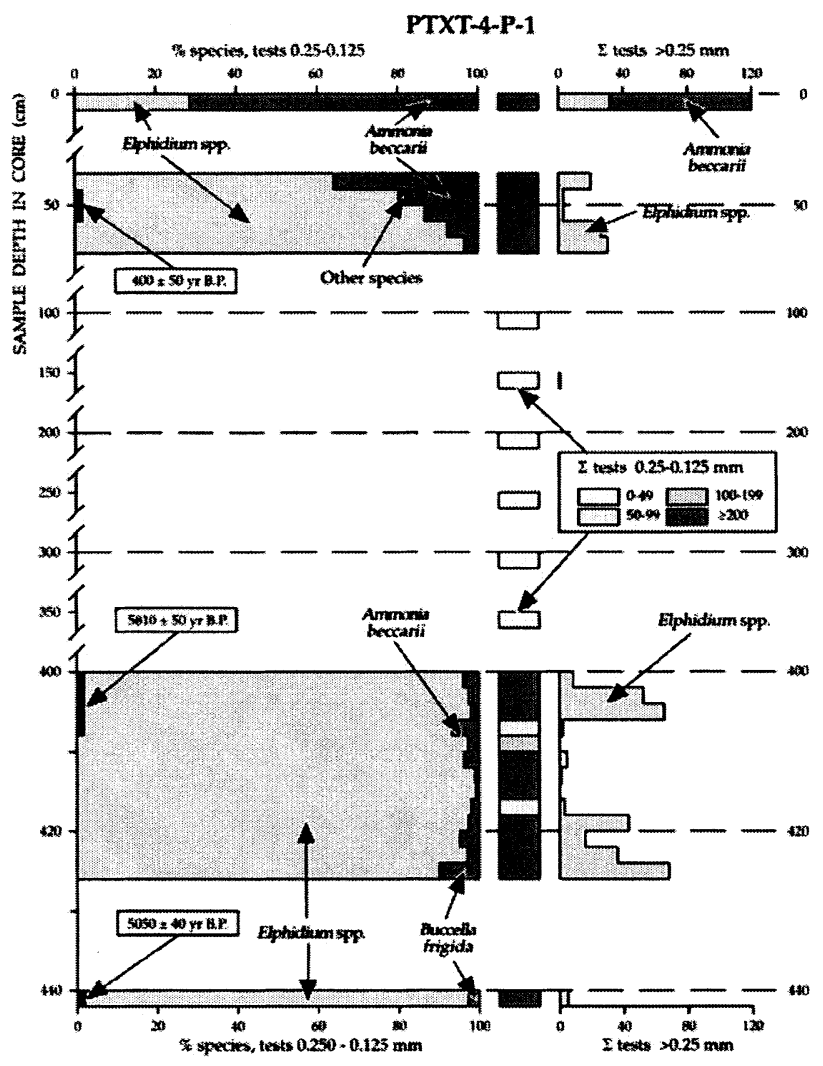

Figure 4 The scheme for this figure is similar to that for Figure 3, except that the full percentage scale is shown for the left column. For the lower core intervals Elphidium spp. again constitutes $\geq 90 \%$ of assemblages, signifying hypersalinity. In the core interval $46-56 \mathrm{~cm}$, for which there is a radiocarbon age of $400 \pm 50 \mathrm{yr} \mathrm{BP}$, the samples record a trend towards dominance of $A$. beccarii, a situation which is clearly apparent in the modern sediment.

surface sample (top of core) revealed that $A$. beccarii is dominant over Elphidium in the modern environment and the five samples around $50 \mathrm{~cm}$ clearly illustrated part of the transition to the present situation about 400 years ago. The 'other species' refers mostly to a few individuals of Ammobaculites sp. Again, samples in which foraminifera were rare or absent may signify increased rates of sedimentation.

Radiocarbon ages derived from analyses of fossil molluscs (Mulinia lateralis) and foraminifera (Table 1) indicate that the older sediments recovered by the cores were deposited in the early to middle Holocene. Because of uncertainties surrounding application of the marine reservoir correction factor to ages derived for estuarine shell materials (Alan Hogg, personal communication, in Cann et al., 2000b), ages are expressed as uncalibrated values.

\section{Discussion}

\section{Significance of Elphidium}

The taxonomy of the morphologically variable Elphidium species that inhabit the modern Chesapeake, and which are preserved as fossils in Holocene sediments of the bay, remains a matter for debate. E. excavatum in the sense of Miller et al. (1982) has several formae (=ecophenotypes) which could accommodate the observations of Ellison and Nichols $(1970 ; 1976)$. More recently, Hayward et al. (1997) have also recognized a range of subspecies for $E$. excavatum, in particular E. excavatum clavatum and $E$. excavatum 
Table 1 Radiocarbon analyses of samples of mollusc shells and foraminifera from cores PTXT-3-P-2 and PTXT-4-P-1. Because of uncertainties surrounding the magnitude of the value that might be applied to estuarine materials, radiocarbon ages are given without correction for the marine reservoir factor

\begin{tabular}{|c|c|c|c|c|}
\hline Laboratory code & Core & Sample depth $(\mathrm{cm})$ & Material analysed & ${ }^{14} \mathrm{C}$ age (yr BP) \\
\hline WW1295 & PTXT-3-P-2 & $350-356$ & mollusc shell Mulinia lateralis & $5960 \pm 50$ \\
\hline WW1296 & PTXT-3-P-2 & $384-386$ & mollusc shell Mulinia lateralis & $6300 \pm 50$ \\
\hline WW1297 & PTXT-3-P-2 & $430-434$ & mollusc shell Mulinia lateralis & $6860 \pm 50$ \\
\hline WW2304 & PTXT-4-P-1 & $48-52$ & mollusc shell fragments & $400 \pm 50$ \\
\hline WW2305 & PTXT-4-P-1 & $400-408$ & mollusc shell fragments & $5810 \pm 50$ \\
\hline WW2306 & PTXT-4-P-1 & $440-442$ & mollusc shell fragments and foraminifera & $5050 \pm 40$ \\
\hline
\end{tabular}

excavatum. For these subspecies they have listed comprehensive synonymies which include references to $E$. clavatum, $E$. incertum and $E$. articulatum. In detailing the geographic distribution of their subspecies, Hayward et al. (1997) have included Elphidium species described by Cann and De Deckker (1981) from saline lakes in South Australia. Cann and De Deckker (1981) documented the ongoing survival of monospecific populations of Elphidium through the seasonal evaporative phases of ephemeral saline lakes. Cann et al. $(2000 \mathrm{a} ; 2000 \mathrm{~b})$ have subsequently referred these forms of Elphidium to E. articulatum in the sense of Murray (1971). Thus, from Chesapeake Bay itself and from other localities, the evidence of dominant Elphidium sp. in fossil foraminiferal assemblages of extremely low diversity, that are preserved in the two Holocene cores, signifies that sedimentation probably occurred in hypersaline waters.

\section{Significance of gypsum}

The euhedral nature of the gypsum crystals in the lower part of PTXT-3-P-2, together with their clarity, signifies crystallization from above the sediment-water interface. The classic model for such chemical precipitation from marine waters in an estuarine or coastal lagoon setting requires evaporative concentration of salinity to about three times that of sea water. The ideal climate is one of high daily temperatures and little or no rainfall, with strong prevailing winds to promote evaporation. When the evaporative brine has reached the concentration at which gypsum begins to crystallize, maintenance of that concentration ensures that crystallization is continuous. The model therefore requires outflow of dense brine that would otherwise precipitate halite, together with inflow of replacement sea water. In the ideal physical setting, there is a sill at the mouth of the lagoon or estuary that restricts access to the ocean and provides potential for density stratification. Thus, a bottom layer of dense brine from which gypsum crystallizes is overlain by a upper layer of evaporating but less dense sea water.

The core site for PTXT-3-P-2 is in the main channel of Chesapeake Bay. Irregular sedimentary infilling of the Cape Charles Channel has ensured that the longitudinal profile of the channel has a number of elongate basins that have the potential for density stratification of saline waters. At the bay mouth there is a restricting sill in the form of a sand wedge. Also, further up the estuary, opposite the mouth of the Rappahannock River, the main channel is blocked by sediment, with deeper water to the north.

In the central part of the modern Chesapeake, salinity is generally about half that of normal sea water (Lippson and Lippson, 1997), waters becoming less saline upstream in bodies such as the Potomac and Patuxent Rivers. Nevertheless, within the Patuxent River, and extending into the main channels of Chesapeake Bay, there is a pronounced salinity stratification which appears to be largely determined by the bathymetry
(Figure 5). This stratification pattern is maintained throughout the year, but is most pronounced in autumn when bottomwater salinity values are higher (Kincaid et al., 1988). Thus the physical setting of the Chesapeake has environments where water-density stratification could have been established in the early Holocene.

In the lowermost sediments of core PTXT-3-P-2, the occurrence of gypsum crystals, together with an almost monospecific assemblage of Elphidium, signify that the water mass of the sedimentary environment was hypersaline. On the basis of this evidence, it would be reasonable to propose that $c .6800$ years ago the Chesapeake had experienced an arid climate which persisted for about a thousand years. Webb et al. (1993) have reviewed lacustrine palaeo-water-levels and fossil pollen data, including those from several sites around Chesapeake Bay, as evidence of late-Pleistocene and Holocene palaeoclimates in eastern North America. They found that for the Chesapeake area the time of maximum warmth was about $6 \mathrm{ka}$ when mean July (summer) temperatures were only $1-2{ }^{\circ} \mathrm{C}$ higher than those of today. Over the period 9 to $6 \mathrm{ka}$, annual precipitation apparently increased from about 1000 to $1200 \mathrm{~mm}$; today the mean annual precipitation for the Chesapeake area is about $1200 \mathrm{~mm}$. In the light of these findings of Webb et al. (1993) it is unlikely that any hypothesis of aridity for the Chesapeake at 6 to $5 \mathrm{ka}$ could be sustained.

What then is the source of the gypsum that has been such a powerful distracter in this palaeoenvironmental investigation? Locally, groundwater within the Miocene St Marys Formation is known to be a potential source of saltwater intrusion, contaminating overlying aquifers by upward leakage (Phelan, 1987). The St Marys Formation crops out above sea level on the western shore of Chesapeake Bay north of the Patuxent

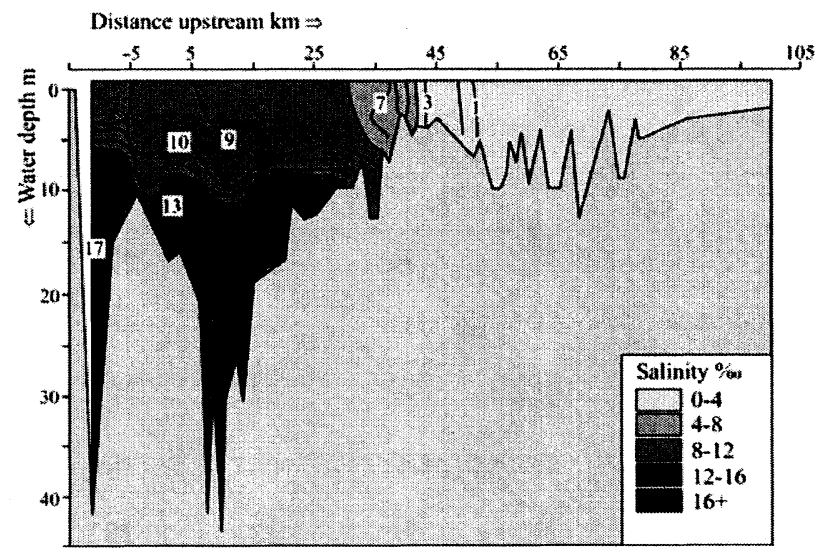

Figure 5 Longitudinal profile of the Patuxent River showing water salinity (\%) determined at a single slack-water event, summer 1984. Note the degree of stratification, especially within the channels of Chesapeake Bay on the left. This pattern is maintained throughout the year, but is most pronounced in autumn. After Kincaid et al. (1988). 
River, and along the southern bank of the Patuxent River where the beds contain large clusters of radiating gypsum crystals (Shattuck, 1904; 1907). It is likely that at the site of core PTXT-3-P-2 the deep Cape Charles palaeochannel has been cut into the St Marys Formation (Colman and Halka, 1989b). Seepage of saline groundwater from these Miocene strata appears to have been the most likely source. A rising water table, concomitant with the postglacial transgression and increased precipitation, may have been a significant factor. Density stratification of waters within the channel was essential for concentration of the contaminant brine to proceed to the point of crystallization.

\section{Conclusions}

Sediments deposited about 6.8 to $5.8 \mathrm{ka}$, adjacent to the Patuxent River in the Cape Charles Channel of Chesapeake Bay, preserve assemblages of fossil foraminifera that are dominated by Elphidium spp. The species signify a palaeoenvironment of hypersaline waters that was at variance with those of the modern Chesapeake, and which did not undergo transition towards present conditions until about 400 years ago. Hypersalinity of bottom waters seems to have been maintained by waterdensity stratification in a basin-like section of the channel. Hypersalinity is also signified by abundant euhedral crystals of gypsum that occur throughout some of the lower sediments. This occurrence of gypsum is attributed to inflow of groundwater from adjacent gypsiferous Miocene strata. Gypsum commonly originates in coastal marine settings of arid climates and its occurrence therefore has potential in palaeoclimatic investigations. However, the study reported here shows that the significance of the presence of gypsum should be evaluated with caution - it does not necessarily signify an evaporative regime.

\section{Acknowledgements}

The authors thank Grant Garven, Lawrence Hardie and Peter Olson for helpful discussions, and two anonymous reviewers for their detailed comments. The work reported here was completed while the senior author was a visitor at the Department of Earth and Planetary Sciences, Johns Hopkins University, Baltimore, USA.

\section{References}

Bradshaw, J.S. 1957: Laboratory studies on the rate of growth of the foraminifer 'Streblus beccarii (Linné) var. tepida (Cushman)'. Journal of Paleontology 32, 1138-47.

1961: Laboratory experiments on the ecology of foraminifera. Contributions from the Cushman Foundation for Foraminiferal Research $12,87-106$.

Buzas, M.A. 1974: Vertical distribution of Ammobaculites in the Rhode River, Maryland. Journal of Foraminiferal Research 4, 144-47.

Cann, J.H. and De Deckker, P. 1981: Fossil Quaternary and living foraminifera from athalassic (non-marine) saline lakes, southern Australia. Journal of Paleontology 55, 660--70.

Cann, J.H., Belperio, A.P. and Murray-Wallace, C.V. 2000a: Late Quaternary paleosealevels and paleoenvironments inferred from foraminifera, Northern Spencer Gulf, South Australia. Journal of Foraminiferal Research 30, 29-53.

Cann, J.H., Bourman, R.P. and Barnett, E.J. 2000b: Holocene foraminifera as indicators of relative estuarine-lagoonal and oceanic influences in estuarine sediments of the River Murray, South Australia. Quaternary Research 53, 378-91.
Chappell, J. and Shackleton, N.J. 1986: Oxygen isotopes and sea level. Nature 324, 137-40.

Chappell, J., Omura, A., Esat, T., McCulloch, M., Pandolfi, J., Ota, Y. and Pillans, B. 1996: Reconciliation of late Quaternary sea levels derived from coral terraces at Huon Peninsula with deep sea oxygen isotope records. Earth and Planetary Science Letters 141, 227-36.

Colman, S.M. and Halka, J.P. 1989a: Maps showing Quaternary geology of the northern Maryland part of the Chesapeake Bay. Department of the Interior, United States Geological Survey, Miscellaneous Field Studies Map MF-1948-D.

1989b: Maps showing Quaternary geology of the southern Maryland part of the Chesapeake Bay. Department of the Interior, United States Geological Survey, Miscellaneous Field Studies Map MF-1948-C. Colman, S.M. and Hobbs, C.H. III 1987: Quaternary geology of the southern Virginia part of the Chesapeake Bay. Department of the Interior, United States Geological Survey, Miscellaneous Field Studies Map MF-1948-A.

1988: Maps showing Quaternary geology of the northern Virginia part of the Chesapeake Bay. Department of the Interior, United States Geological Survey, Miscellaneous Field Studies Map MF-1948-B.

Cronin, T.M. and Ishman, S.E. 2000: Holocene paleoclimate from Chesapeake Bay ostracodes and benthic foraminifera from MarionDufresne core MD99-2209. In Cronin, T.M., editor, Initial report on IMAGES $V$ cruise of the Marion-Dufresne to the Chesapeake Bay, June 20-22, 1999, United States Geological Survey Open-file Report 00-306, 93-101.

Cronin, T., Colman, S., Willard, D., Kerhin, R., Holmes, C., Karlsen, A., Ishman, S. and Bratton, J. 1999: Interdisciplinary environmental project probes Chesapeake Bay down to the core. Eos, Transactions, American Geophysical Union 80, 237 and 240-41.

Cronin, T., Willard, D., Karlsen, A., Ishman, S., Verado, S., McGeehin, J., Kerhin, R., Holmes, C., Colman, S. and Zimmerman, A. 2000: Climatic variability in the eastern United States over the past millennium from Chesapeake Bay sediments. Geology 28, 3-6.

Culver, S.J. and Buzas, M.A. 1980: Distribution of recent benthic foraminifera off the North American Atlantic coast. Smithsonian Contributions to the Marine Sciences 6, 1-512.

1981: Recent benthic foraminiferal provinces on the Atlantic continental margin of North America. Journal of Foraminiferal Research $11,217-40$.

Ellison, R.L. 1972: Ammobaculites, foraminiferal proprietor of the Chesapeake Bay estuaries. In Nelson, B.W., editor, Environmental framework of coastal plain estuaries, Geological Society of America, Memoir 133, 247-62.

Ellison, R.L. and Nichols, M.M. 1970: Estuarine foraminifera from the Rappahannock River, Virginia. Contributions from the Cushman Foundation for Foraminiferal Research 21, 1-17.

_ 1976: Modern and Holocene foraminifera in the Chesapeake Bay region. In Schafer, C.T. and Pelletier, B.R., editors, First International Symposium on Benthonic Foraminifera of the Continental Margins. Part A - Ecology and Biology: Maritime Sediments, Special Publication 1, $131-51$.

Ellison, R.L., Nichols, M.M. and Hughes, J. 1965: Distribution of Recent foraminifera in the Rappahannock River Estuary. Virginia Institute of Marine Science, Special Science Report 47, 1-35.

Halka, J.P., Vogt, P.R., Colman, S.M. and Cronin, T.M. 2000: Geophysical environment: site MD99-2209. In Cronin, T.M., editor, Initial report on IMAGES V cruise of the Marion-Dufresne to the Chesapeake Bay, June 20-22, 1999, United States Geological Survey Open-file Report 00-306, 40-48.

Hayward, B.W., Hollis, C.J. and Grenfell, H.R. 1997: Recent Elphidiidae (Foraminiferida) of the south-west Pacific and fossil Elphidiidae of New Zealand. Institute of Geological and Nuclear Sciences Monograph $16,1-170$.

Ishman, S.E., Karlsen, A.W. and Cronin, T.M. 1999: Chesapeake Bay benthic foraminifera. In Cronin, T.M., Wagner, R.S. and Slattery, M., editors, Microfossils from Chesapeake Bay sediments: illustrations and species database, United States Geological Survey Open-file Report 99-45, 10-53. Also available as an internet publication at: http://pubs.usgs.gov/pdf/of/of99-45/foram.pdf/gov/pdf (last accessed February 2004).

Karlsen, A.W., Cronin, T.M., Ishmæn, S.E., Willard, D.A., Holmes, C.W., Marot, M. and Kerhin, R. 2000: Historical trends in Chesapeake 
Bay dissolved oxygen based on benthic foraminifera from sediment cores. Estuaries 23, 488-508.

Kerhin, R.T., Williams, C. and Cronin, T.M. 1998: Lithologic descriptions of piston cores from Chesapeake Bay, Maryland. United States Geological Survey Open-file Report 98-787.

Kincaid, C., Olson, P. and Wang, H. 1988: A numerical investigation of circulation and salt distribution in the Patuxent River estuary. Understanding the estuary: advances in Chesapeake Bay research. Conference Proceedings. Chesapeake Research Consortium 129, 323-51.

Lippson, A.J. and Lippson, R.L. 1997: Life in the Chesapeake Bay (second edition). Baltimore: The Johns Hopkins University Press.

Miller, A.A.L., Scott, D.B. and Medioli, F.S. 1982: Elphidium excavatum (Terquem): ecophenotypic versus subspecific variation. Journal of Foraminiferal Research 12, 116-44.

Murray, J.W. 1971: An atlas of British Recent foraminiferids. London Heinemann Educational Books.

Nichols, M.M. and Norton, W. 1969: Foraminiferal populations in a coastal plain estuary. Palaeogeography, Palaeoclimatology, Palaeoecology 6, 197-213.

Phelan, D.J. 1987: Water levels, chloride concentrations, and pumpage in the coastal aquifers of Delaware and Maryland. United States Geological Survey Water-resources Investigations Report 87-4229.

Shattuck, G.B. 1904: Geological and paleontological relations, with a review of earlier investigations. In Miocene, Baltimore: Maryland Geological Survey, 33-115.
1907: The Geology of St Mary's County. In Maryland Geological Survey, St Mary's County, Baltimore: The Johns Hopkins Press, $67-112$.

United States Geological Survey 1998: The Chesapeake Bay - geologic product of rising sea level. United States Geological Survey Fact Sheet FS 102-98.

Vogt, P.R., Czarnecki, M. and Halka, J.P. 2000a: Marion-Dufresne coring in Chesapeake Bay: Geophysical environment at site MD992204 and 2207. In Cronin, T.M., editor, Initial report on IMAGES V cruise of the Marion-Dufresne to the Chesapeake Bay, June 20-22, 1999, United States Geological Survey Open-file Report 00-306, 32-39.

Vogt, P.R., Halka, J.P., Hagan, R.A. and Cronin, T.M. 2000b: Geophysical environment in Chesapeake Bay: Marion-Dufresne sites MD99-2205, 2206, 2208. In Cronin, T.M., editor, Initial report on IMAGES V cruise of the Marion-Dufresne to the Chesapeake Bay, June 20-22, 1999, United States Geological Survey Open-file Report 00-306, $18-31$

Webb, T. III, Bartlein, P.J., Harrison, S.P. and Anderson, K.H. 1993: Vegetation, lake levels, and climate in eastern North America for the past 18,000 years. In Wright, H.E. Jr, Kutzbach, J.E., Webb T. III, Ruddiman, W.F., Street-Perrott, F.A., and Bartlein, P.J., editors, Global climates since the last glacial maximum, Minneapolis: University of Minnesota Press, 415-67. 